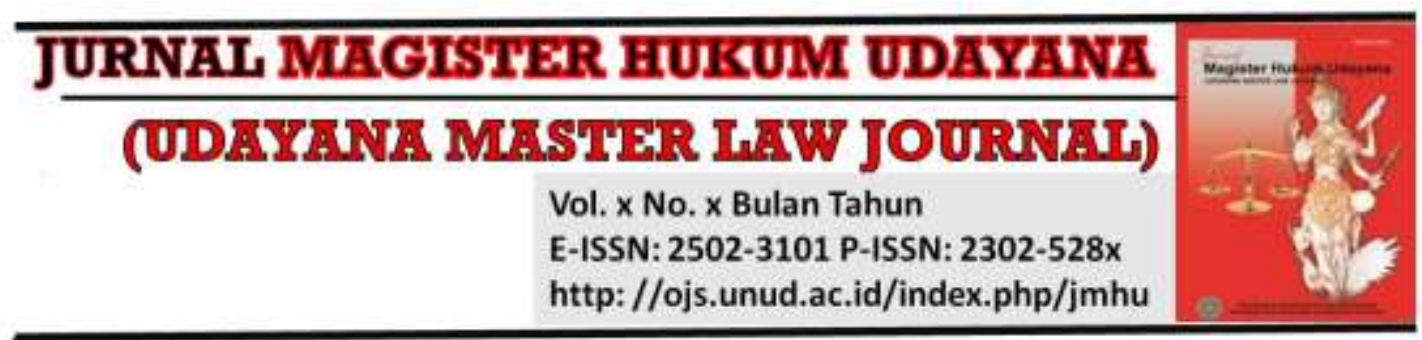

\title{
Perlindungan Konsumen dari Penyebarluasan Data Pribadi oleh Pihak Ketiga: Kasus Fintech Peer To Peer Lending
}

\author{
Veronica Novinna ${ }^{1}$ \\ 1 Program Studi Magister Ilmu Hukum, Fakultas Hukum Universitas Indonesia, \\ Email: novinna13veronica@gmail.com
}

\begin{tabular}{l}
\hline Info Artikel \\
\hline Masuk: 1 Nopember 2019 \\
Diterima: 25 Pebruari 2020 \\
Terbit: 31 Mei 2020 \\
Keywords: \\
Consumer protection; Personal \\
data; Debt collector; Online \\
loans; Peer to Peer Lending \\
\\
\\
\\
Kata kunci: \\
Perlindungan Konsumen; Data \\
Pribadi; Debt collector; \\
Pinjaman Online; Peer to Peer \\
Lending \\
Corresponding Author: \\
Veronica Novinna, Email: \\
novinna13veronica@gmail.com \\
DOI: \\
10.24843/JMHU.2020.v09.i01. \\
p07
\end{tabular}

\begin{abstract}
Online loans are an instant method to get loans with technology basis and under control of the Financial Services Authority. Startups organizer have failed to protect consumers personal information thus creates problem in collecting debts. This study aims to explain and analyze the Legal Position of the Debt Collector in the administration of fintech and the legal consequences of the act of suppressing payments to consumers who fail to pay unlawfully. This type of research used is normative juridical conducted with the approach of existing laws and regulations in Indonesia. Based on the research results obtained, there is a relationship or position of a third party with an online loan provider as a debt collector in a loan default, and this is explicitly explained in the P2P Lending fintech service delivery guidelines. The legal consequences of the act of suppressing payments in the form of distribution consumer personal data from the debt collector of the party organizing P2P Lending where the consumer has the right to get legal protection through the filing of a claim of loss arising as well as the organizer may be subject to administrative sanctions for his negligence.
\end{abstract}

\begin{tabular}{l}
\hline Abstrak \\
\hline Pinjaman online ialah pinjaman cepat berbasis teknologi yang \\
diawasi oleh OJK, beberapa penyelenggara telah lalai dalam \\
menjaga data pribadi konsumen sehingga menimbulkan \\
permasalahan dalam penagihan hutang kepada konsumen. \\
Penelitian ini bertujuan untuk menjelaskan dan menganalisis \\
Kedudukan Hukum Debt collector dalam penyelenggaraan \\
fintech dan akibat hukum terhadap tindakan menekan \\
pembayaran kepada konsumen gagal bayar dengan cara melawan \\
hukum". Jenis Penelitian yang dipergunakan ialah yuridis \\
normatif yang dilakukan dengan pendekatan peraturan \\
perundang-undangan yang ada di Indonesia. Berdasarkan hasil \\
penelitian yang didapat yakni adapun hubungan atau kedudukan \\
pihak ketiga dengan penyelenggara pinjaman online adalah \\
sebagai penagih hutang dalam pinjaman gagal bayar dan hal \\
tersebut dijelaskan secara eksplisit dalam pedoman perilaku \\
pemberian layanan fintech Peer to Peer Lending (P2P \\
Lending)."Adapun akibat hukum terhadap tindakan menekan \\
pembayaran berupa penyebaran data pribadi konsumen dari debt \\
collector pihak penyelenggara P2P Lending dimana konsumen
\end{tabular}


berhak mendapat perlindungan hukum melalui pengajuan tuntutan kerugian yang timbul serta pihak penyelenggara dapat dikenakan sanksi administratif atas tindakan kelalaiannya.

\section{Pendahuluan}

Perkembangan globalisasi yang semakin membuat perubahan besar terhadap segala aktivitas yang dilakukan oleh manusia terutama di bidang teknologi. Perkembangan teknologi dari tahun ke tahunnya telah membawa dampak positif, khususnya dalam masalah ekonomi seperti financial technology atau sering disebut Fintech. Perkembangan Fintech pada saat ini dibantu oleh internet, dengan tumbuhnya hal tersebut maka secara pasti mendorong munculnya banyak perusahaan start up dalam sektor keuangan dalam hal pinjaman online yang berbasis teknologi informasi atau fintech peer to peer Lending atau biasa disebut P2P Lending. Ini sangat mirip dengan perantara digital yang menghubungkan antara pihak satu dengan pihak lainnya (peminjam dana dan pemberi pinjaman dana). ${ }^{1}$ Konsep ini memberikan kesempatan pada setiap orang untuk menjadi investor dalam memberikan pinjaman dana ataupun memberikan kesempatan pada setiap orang yang membutuhkan tanpa perlu perantara ataupun melewati jasa dari pihak lembaga keuangan. Berdasarkan penjelasan tersebut Fintech P2P Lending diharapkan mampu memberikan sebuah solusi kepada masyarakat dalam hal peminjaman uang dengan cepat, cara ini lebih modern untuk mendapatkan dana dalam bentuk pinjaman usaha.

Adapun perkembangan Fintech di dunia sudah mulai ada pada tahun 1950, yang dimana Fintech dalam perkembangannya adalah sektor yang luas dan apabila dilihat sampai saat ini dari perkembangan tersebut telah memberikan evolusi fintech yang berkelanjutan, 2 seperti adanya fasilitas kartu kredit untuk meringankan beban membawa uang tunai. ${ }^{3}$ Pada abad ke-21 ini, layanan keuangan telah pindah melalui dompet seluler, aplikasi pembayaran, yang dimana layanan Fintech bukan tambahan sederhana untuk layanan perbankan, melainkan menggantikan layanan perbankan sepenuhnya. ${ }^{4}$

Dalam jurnal yang berjudul Infinite Dinancial Intermediation yang ditulis oleh Tom C.W.Lin menjelaskan bahwa tujuan dari adanya Fintech adalah sebagai inovasi di bidang teknologi dalam melakukan penyampaian layanan serta meningkatkan kegiatan di bidang keuangan yang cepat dan efisien tanpa perlu memakan waktu yang cukup lama adanya fintech ini untuk bersaing dengan metode keuangan tradisional. ${ }^{5}$ Ini merupakan salah satu tujuan dari adanya intermediasi keuangan yang membuat transaksi keuangan jadi lebih efisien karena adanya perantara sebagai pihak yang

1 Tanja Jorgensen (2018). Peer to Peer Lending - A New Digital Intermediary, New Legal Challenges. Nodic Journal of Commercial Law. Doi: https://doi.org/10.5278/ojs.njcl.v0i1.2491.

2 Fagulni Desai. (2015). The Evolution of Fintech . retrieved from: https://www.forbes.com/sites/falgunidesai/2016/12/13/the-evolutions-ofFintech/\#6fe5029d7175

3 Ibid

4 Ibid

5 Tom.C. W. Lin (2015). Infinite Financial Intermediation. Wake Forest Law Review .No.201606.Vol. 50, No. 643, 2015.p.646 
menghubungkan konsumen selaku nasabah dan konsumen selaku pemberi dana bagi pihak yang memerlukan pembiayaan.

Fintech adalah produk financial dan jasa melalui penggabungan platform teknologi dan model bisnis yang inovatif adapun asal-usul fintech itu sendiri datang dari Silicon Valley salah satu bagian selatan dari San Fansisco Bay Area di California, kemudian berkembang ke New York, Singapore, Hong Kong, dan beberapa negara global. ${ }^{6}$ Di negara asia seperti Singapura merupakan tempat di mana teknologi dan kepercayaan membentuk dasar untuk lini keuangan yang inovatif jasa. Pinjaman Peer to Peer telah mengakar di Singapura dan dihargai karena langsung menghubungkan pihak peminjam dan penerima pinjaman. Singapura memiliki ekonomi intensif uang tunai di mana banyak peminjaman dan peminjaman sudah dilakukan di luar Singapura, ini adalah salah satu alasan yang membuat Singapura kondusif untuk pengembangan sistem kredit alternatif, terutama pengembangan platform pinjaman online yang bertujuan untuk menyediakan akses modal ke UKM.7 Sementara itu di Indonesia ada startup yang sudah menghasilkan sekitar US \$ 56 juta. Pendanaan Fintech adalah pasar pinjaman peer-to-peer di mana pemberi pinjaman pihak ketiga menyediakan uang tunai dan dimana mendapatkan keuntungan dalam pengembaliannya. ${ }^{8}$

Layanan P2P lending adalah solusi untuk menjawab permasalahan layanan keuangan perbankan yang tidak tersentuh oleh sebagian masyarakat karena faktor geografis. $P 2 P$ Lending bekerja layaknya seperti bank namun cara kerjanya melalui internet dan teknologi canggih yang dimana peminjaman atau hutang biasanya dilakukan dengan perjanjian bahwa pihak yang memilki dana akan meminjamkannya kepada pihak yang kekurangan dana dengan berdasarkan prinsip "freedom of contract" yang diatur dalam KUHPerdata. Berdasarkan perkembangan tersebut maka dapat dikatakan kegiatan usaha di bidang Fintech sangatlah efisien, karena tidak membutuhkan banyak sumber daya manusia dalam menjalankan usahanya. Fintech terlihat lebih efisien karena dapat menekan biaya operasional sehingga dapat menyalurkan pembiayaan dengan proses yang lebih cepat. ${ }^{9}$ Di Indonesia Fintech P2P Lending diawasi oleh Otoritas Jasa Keuangan (OJK), sebagai Lembaga Pemerintahan Non Kementerian yang dibentuk oleh Pemerintah Indonesia berdasarkan Undang-Undang Nomor 21 Tahun 2011 tentang Otoritas Jasa Keuangan pada pasal 6 menjelaskan tugas utama OJK yakni melakukan pengaturan dan pengawasan terhadap kegiatan jasa keuangan di sector Perbankan, Pasar Modal, dan kegiatan jasa keuangan di sector Perasuransian, Dana Pensiun, Lembaga Pembiayaan, dan Lembaga Jasa Keuangan lainnya. Lebih lanjut lagi, dalam POJK P2P Lending dalam pasal 8 dijelaskan mengenai permohonan pendaftaran kepada OJK bagi penyelenggara yang ingin melakukan kegiatan layanan pinjam meminjam uang berbasis teknologi informasi secara administrasi, lebih jauh lagi, bagi penyelenggara layanan pinjaman online yang sudah memiliki izin dari OJK diwajibkan untuk menyampaikan laporan bulanan dan laporan tahunan berkala secara

6 Anita, Siti Zulaikha, Khofidlotur Rofiah, \& Risa Sari Pertiwi. (2019). Legal Protection of Lenders in the Implementation of Financial Technology Based on Peer to Peer Lending. KnE Social Sciences, pages 1305-1316. DOI 10.18502/kss. v3i13.4286, page.1307.

7 U Yunus. (2018). A Comparison Peer to Peer Lending Platforms in Singapore and Indonesia. Journal of Physics: Conference Series. doi:10.1088/1742-6596/1235/1/012008. p.1.

8 Ibid.

9 Ridwan Muchlis. (2018). Analisis SWOT Financial Technology (Fintech) Pembiayaan Perbankan Syariah Di Indonesia (Studi Kasus 4 Bank Syariah Di Kota Medan) . Jurnal AtTawassuth: Ekonomi Syariah Universitas Islam Negeri Sumatera Utara.v.3.no.3.2018.h.335-357 
elektronik kepada OJK, dan ini diatur pada pasal 44 POJK P2P Lending. Ini berarti OJK sebagai Lembaga Negara memiliki wewenang dalam melakukan pengaturan dan pengawasan terhadap siapa saja yang melakukan kegiatan penyelenggaraan fintech P2P Lending yang telah terintegrasi dan terdaftar dengan OJK. Dalam hal pengawasan, OJK hanya mengawasi penyelenggara pihak yang terdaftar secara legal saja

Sebagai layanan keuangan pinjaman online yang berbasis teknologi, P2P Lending dirasa sangat menguntungkan karena hanya dengan syarat Kartu Tanda Penduduk (KTP), foto, dan nomor rekening memudahkan para pihak khususnya konsumen dalam melakukan pinjaman dan mendapatkan dana dalam waktu yang singkat. Meskipun administrasi diatur dengan ketat, Fintech yang berbasis P2P Lending ini tetap saja menimbulkan beberapa permasalahan dalam menjalankan usahanya walaupun dari segi layanan, Fintech cara kerjanya terlihat lebih efisien dari lembaga keuangan konvensional sebelumnya.

Setiap hal yang positif sudah tentu diikuti dengan hal negative, hal tersebut cocok untuk dikatakan pada layanan P2P lending. Apabila dilihat dari sisi perlindungan konsumen kehadiran pinjaman online ini menimbulkan banyak permasalahan bahkan sampai meregang nyawa konsumen selaku nasabah pinjaman online berbasis teknologi ini. Berkaitan mengenai beberapa permasalahan yang masuk ke Lembaga Bantuan Hukum (LBH) Jakarta adalah tingginya biaya bunga yang harus dibayar nasabah, proses penagihan yang tidak wajar seperti fitnah, ancaman, pengancaman, termasuk melakukan penyebaran data pribadi ke pihak-pihak lain yang tentunya hal ini merugikan konsumen selaku nasabah pinjaman online serta mengganggu kenyamanan orang lain. ${ }^{10}$

Jauh sebelum kasus di atas muncul ke permukaan, sebagai Lembaga yang mengawasi aktivitas keuangan di Indonesia, OJK sebelumnya sudah menerbitkan peraturan yang berkaitan dengan fintech P2P Lending yaitu Peraturan Otoritas Jasa Keuangan Nomor 77 tahun 2016 tentang Layanan Pinjam Meminjam Uang Berbasis Teknologi Informasi (POJK Layanan P2P Lending). Peraturan ini mewajibkan setiap orang selaku pelaku usaha yang berkecimpung dalam bisnis pinjaman berbasis teknologi informasi harus mendaftarkan usahanya secara resmi. Peraturan ini dinilai kurang tegas karena masih banyak pelaku usaha dengan aplikasi ilegalnya tetap menjalankan usaha sehingga menimbulkan permasalahan. ${ }^{11}$ Salah satu contoh kasus Fintech P2P Lending yang bermasalah adalah Rupiah Plus, yang melakukan penagihan uang kepada konsumennya dengan cara tidak wajar seperti mengakses kontak telepon pribadi konsumen tanpa pemberitahuan terlebih dahulu serta menghubungi semua pihak yang ada dalam kontak telepon konsumen dengan memberitahukan data pribadi peminjam dan jumlah hutang yang harus dibayar, dari hal tersebut muncul pertanyaan bagaimana sebenarnya efektifitas hukum di Indonesia dalam melindungi data pribadi konsumen terutama terhadap konsumen selaku penerima pinjaman dalam P2P Lending.

${ }^{10}$ Yudho Winarto, (2018), LBH Jakarta Terima 500 Pengaduan Terkait Fintech Bermasalah, available from: https://keuangan.kontan.co.id/news/lbh-jakarta-terima-500-pengaduanterkait-fintech-bermasalah?page=all.

11 Ibid. 


\section{Metode Penelitian}

Penelitian hukum ialah suatu kegiatan dilakukan atas dasar sistematika yang jelas mulai dari metode dan pemikiran yang memiliki tujuan untuk mempelajari suatu gejala hukum yang terjadi di sekitar masyarakat. ${ }^{12}$ Dalam tulisan ini, adapun metode yang digunakan dalam tulisan ini ialah penelitian hukum normatif, dimana hukum penelitian yang dilakukan dengan cara meneliti bahan pustaka atau data sekunder, ${ }^{13}$ bukan hanya mengkaji hukum dari segi peraturan perundang-undangan saja namun meliputi aspek yang lebih luas lagi dan dapat ditelusuri dan bahan kepustakaan. Pendekatan yang digunakan di dalam tulisan ini ialah pendekatan peraturan perundang-undangan yaitu meneliti berbagai aturan hukum yang berkaitan dengan isu yang diangkat. ${ }^{14}$ Adapun bahan hukum yang digunakan ada dua jenis yaitu bahan hukum primer yang berkaitan dengan aturan hukum terkait data pribadi dan layanan pinjaman online berbasis teknologi informasi seperti POJK Layanan P2P Lending, peraturan hukum perlindungan data pribadi. Kemudian untuk bahan hukum sekunder berupa literatur atau buku, jurnal internasional dan nasional, serta literatur lainnya yang berkaitan dengan pembahasan perlindungan konsumen atas penyebarluasan data pribadi.

\section{Hasil dan Pembahasan}

\subsection{Kedudukan Hukum Debt collector dalam Penyelenggaraan Fintech}

\subsubsection{Hubungan Pihak Ketiga dengan Penyelenggara Pinjaman Berbasis Teknologi Informasi dalam Financial Technology Peer to Peer Lending}

Mekanisme dalam penagihan hutang pada penyelenggaraan pinjaman online sering sekali menjadi masalah terutama terhadap konsumen seperti cara penagihan lewat telepon yang dilakukan dengan kasar dan tidak semestinya. Adapun kedudukan hukum debt collector di dunia perbankan sudahlah sangat umum dan biasanya mereka digunakan saat terjadi kredit dengan kolektibilitas macet, maka dari itu pihak bank bekerja sama dengan debt collector untuk melakukan penagihan atau penyelesaian kredit yang macet dan hal tersebut diatur dalam PBI 11/11/2009. ${ }^{15}$ Adanya hubungan kerja sama antara pihak ketiga selaku debt collector dan pihak bank, debt collector selaku pihak ketiga harus melakukan kewajibannya yang diminta oleh pihak bank untuk melakukan penagihan hutang terhadap nasabah yang dinilai gagal bayar terhadap hutangnya, maka tugas debt collector di sini untuk memastikan bahwa nasabah memenuhi janjinya untuk melakukan pelunasan hutang. Debt collector adalah jembatan penghubung antara nasabah dan pihak bank dalam hal penagihan uang hutang.

Merujuk pada peraturan tersebut, apabila melihat ketentuan dalam kode etik pedoman perilaku pemberian layanan fintech $P 2 P$ Lending yang dikeluarkan oleh Asosiasi

12 Soerjono Soekanto. (2007). Pengantar Penelitian Hukum. Cet.III. Jakarta. Universitas Indonesia. h. 43.

13 Soerjono Soekanto, Sri Mamuji. (2010). Penelitian Hukum Normatif suatu Tinjauan Singkat. Jakarta: Raja Grafindo Persada, h. 13.

14 Abdulkadir Muhammad. (2004). Hukum dan Penelitian Hukum, Cet. 1. Bandung: PT. Citra Aditya Bakti, h. 49.

15 Republik Indonesia Peraturan Bank Indonesia Tentang Penyelenggaraan Kegiatan Alat Pembayaran Dengan Menggunakan Kartu . PBI No. 11/11/ PBI Tahun 2009. LN Tahun 2009 No. 64 DASP. TLN No. 5000. Diundangkan Tanggal 13 April 2009. 
Fintech Pendanaan Indonesia (AFPI) di sana terdapat penjelasan mengenai penggunaan pihak ketiga (debt collector) dalam penagihan hutang, adapun hubungan pihak ketiga sebagai debt collector dengan penyelenggara pinjaman online $P 2 P$ Lending adalah selaku pihak yang menjadi penghubung dalam penagihan atas pinjaman gagal bayar oleh nasabah selaku penerima pinjaman, namun dalam hal ini pihak ketiga tersebut harus menjadi bagian atau anggota dari AFPI sesuai dengan apa yang diatur dalam pedoman. Adapun bentuk hubungan hukum antara pihak penyelenggara dengan debt collector selaku pihak ketiga berupa perikatan yang muncul yang membuat mereka memiliki tugasnya masing-masing untuk pemenuhan prestasi, hubungan ini muncul saat adanya standard contract yang sudah dirundingkan dan disetujui oleh keduanya, dan pihak ketiga selaku debt collector akan bekerja apabila pihak penyelenggara mengeluarkan surat kuasa. ${ }^{16}$ Hubungan debt collector dengan penyelenggara dilihat dari syarat perjanjian yang sah adalah hubungan yang dilakukan karena terjadinya kesepakatan dari masing-masing pihak yang menghasilkan kewajiban dan tugasnya masing-masing. ${ }^{17}$ Dalam perjanjian pertama antara pihak penyelenggara Fintech $P 2 P$ Lending dengan pihak penerima pinjaman online merupakan sebuah perjanjian dua pihak, maka dari itu adanya pemberitahuan oleh pihak penyelenggara $P 2 P$ Lending berkaitan dengan pemberian kuasa kepada pihak ketiga apabila terjadi gagal bayar dalam pinjaman online harus diketahui oleh yang bersangkutan .

\subsubsection{Kode Etik Penagihan Hutang yang Baik Oleh Penyelenggara Pinjaman Online Berbasis Teknologi Informasi atau Peer to Peer Lending}

Dalam Penyelenggaraan $P 2 P$ Lending sudah terdapat beberapa kasus yang meresahkan konsumen selaku penerima pinjaman dana terutama terkait tingginya suku bunga dari pinjaman dan cara penagihan yang merugikan konsumen akibat gagal bayar dengan melakukan pencemaran nama baik dan hal tersebut sudah dirasa melanggar aturan. Guna mendukung layanan keuangan Indonesia, sebagai Lembaga resmi yang ditunjuk oleh OJK lewat surat No. S-5/D.05/2019 sebagai asosiasi yang secara resmi dalam penyelenggaraan P2P Lending, lembaga ini diresmikan secara langsung oleh OJK pada tanggal 5 Oktober 2018. Asosiasi Fintech Pendanaan Indonesia atau disingkat AFPI memiliki peran penting membantu OJK terutama dalam hal pengaturan kebijakan serta pengawasan terhadap para pelaku usaha yang melakukan kegiatan usaha pinjaman online Fintech P2P Lending sesuai dengan POJK Layanan P2P Lending dalam Bab XIII pasal 48.

Sesuai pedoman perilaku pemberian layanan fintech P2P Lending yang dikeluarkan oleh AFPI sebagai pedoman untuk penyelenggara yang menjalankan usaha pinjam meminjam online, setiap pelaku usaha selaku penyelenggara pinjaman online sudah pasti mengenal prinsip good faith karena prinsip tersebut wajib diterapkan setiap orang dalam menjalankan usaha dan dalam hal ini prinsip itu harus diterapkan dalam melakukan fasilitas kegiatan penawaran sebagai platform (wadah dalam pinjaman online) atau marketplace, itu karena pelaku usaha harus memperhatikan kepentingan pihak terkait baik pemberi pinjaman ataupun penerima pinjaman yang terlibat tanpa

16 Risky Saputra (2018). Analisis Hukum Penggunaan Jasa Pihak Ketiga (Debt collector) Dalam Upaya Penyelesaian Kartu Kredit Macet Pada Bank Danamon Indonesia Tbk (Studi Putusan No. 751/PDT.G/2014/PN.JAK.SEL). Jurnal Civil Law.Vol 1. No 6 (2018). h. 23.

17 Lihat Republik Indonesia. Kitab Undang-Undang Hukum Perdata . Staatsblaad No. 23 Tahun 1847. Diundangkan Tanggal 30 April 1847. Ketentuan Pasal 1320. 
merendahkan harkat martabat pengguna oleh penyelenggara. ${ }^{18}$ Pihak penyelenggara wajib dalam proses penagihan hutang atas pinjaman gagal bayar menerapkan prinsip good faith atau itikad baik, seperti:

a. Prosedur penyelesaian dan penagihan hutang yang gagal bayar wajib diberitahukan kepada pihak pemberi dan juga pihak penerima pinjaman online oleh Penyelenggara pinjaman online

b. Penyampaian langkah-langkah yang ditempuh dalam penyelesaian apabila terjadi gagal bayar atas pinjaman uang oleh konsumen selaku peminjam uang patut untuk diberitahukan kepada peminjam yang bersangkutan, adapun langkah-langkahnya antara lain: ${ }^{19}$

1. Pihak penyelenggara mengeluarkan surat peringatan untuk nasabah

2. Restrukturisasi pinjaman atau perbaikan kegiatan perkreditan bagi debitur yang dirasa sulit untuk pemenuhan kewajibannya

3. Saat terjadi gagal bayar, pihak penyelenggara melakukan korespondensi secara jarak jauh (desk collection) dengan konsumen selaku penerima pinjaman dana, korespondensi dilakukan melalui via telepon, email, ataupun dengan melalui bentuk-bentuk percakapan lainnya;

4. Pihak penyelenggara wajib untuk memberitahukan sebelumnya mengenai kunjungan atau komunikasi melalui debt collector;

5. Pinjaman yang dihapuskan.

c. Sertifikasi untuk para debt collector P2P sebagai pihak ketiga penagih hutang wajib dimiliki seluruh karyawan internal debt collector, dan sertifikasi agen penagihan harus dikeluarkan dengan mekanisme serta seleksi yang ketat oleh AFPI;

d. Apabila sudah jatuh tempo dan melewati sembilan puluh hari maka tidak diperkenankan untuk menagih hutang secara langsung kepada nasabah yang gagal untuk membayar pinjamannya kepada pihak penyelenggara secara langsung;

e. Sebagai Pihak penyelenggara pinjaman online fintech P2P Lending wajib untuk melakukan pemberitahuan terhadap peminjam risiko secara rinci tentang hal apa saja yang akan diterima ke depannya apabila mereka tidak menyelesaikan kewajibannya sampai selesai.

f. Kepentingan Konsumen selaku pemberi pinjaman dan konsumen penerima pinjaman dana wajib diperhatikan oleh pihak penyelenggara pinjaman online fintech P2P Lending dalam melakukan prosedur penyelesaian dan penagihan kepada masing-masing pihak.

Penggunaan pihak ketiga diizinkan dalam penyelenggaraan pinjaman online Fintech P2P Lending hanya apabila sudah memenuhi persyaratan pihak ketiga memiliki sertifikasi serta terdaftar di AFPI dan apabila sudah memenuhi syarat maka debt collector selaku pihak ketiga sebagai perwakilan dari pihak penyelenggara dapat melakukan penagihan kepada peminjam, jadi dengan kata lain apabila pihak ketiga yang dimaksud masuk dalam daftar hitam asosiasi atau otoritas maka itu tidak diperbolehkan. Adapun larangan Penyelenggara Fintech $P 2 P$ Lending dalam melakukan kegiatan penagihan pinjaman gagal bayar kepada konsumen selaku penerima pinjaman yaitu pihak ketiga selaku debt collector tidak diperbolehkan

18 Asosiasi Fintech Pendanaan Indonesia. Pedoman Perilaku. available from: https://www.afpi.or.id/detailsnews / pedoman - perilaku. Tanggal 17 Oktober 2019

19 Ibid. 
menggunakan cara intimidasi, seperti kekerasan fisik dan mental, ataupun menyinggung Suku, Agama, Ras, dan Antar Golongan (SARA), termasuk menggunakan cara yang merendahkan manusia dan hal tersebut juga berlaku pada kerabat dan keluarga penerima pinjaman.

\subsection{Upaya Pemerintah Indonesia Dalam Memberikan Perlindungan Data Pribadi Konsumen Selaku Penerima Pinjaman Online di Indonesia}

Konsumen adalah orang atau perseorangan atau badan hukum yang ada dalam produk atau layanan yang ditawarkan dalam pasar, mereka dianggap sebagai konsumen akhir dalam penggunaan produk atau layanan yang ditawarkan . ${ }^{20}$ Konsumen dalam pinjaman online fintech P2P Lending yakni konsumen sebagai salah satu pihak yang menjadi faktor pendukung dalam berkembangnya bisnis fintech, sebagai konsumen yang memberikan dananya serta konsumen yang menggunakan dana yang dipinjamnya melalui Lembaga Jasa Keuangan yang ada dalam sector jasa keuangan, ${ }^{21}$ Adapun perbedaan dari kedua pihak tersebut adalah bisa dilihat dari tujuan penggunaan layanan platform P2P Lending. ${ }^{22}$

Dalam Hukum perlindungan konsumen yang diatur di Indonesia, hanya menjelaskan pihak orang/badan usaha yang melakukan kegiatan usaha di wilayah Indonesia disebut sebagai pelaku usaha, ${ }^{23}$ yang apabila dikaitkan dengan pinjaman berbasis teknologi informasi yang dalam hal ini adalah platform dari Fintech P2P Lending itu sendiri harus berbentuk badan hukum Perseoran Terbatas atau Koperasi. Pelaku usaha dalam menjalankan kegiatannya sudah tentu memerlukan orang lain agar timbul suatu perjanjian, karena perjanjian merupakan kesepakatan yang sifatnya timbal balik. Perjanjian merupakan perbuatan yang dilakukan antar pihak-pihak baik itu dua orang ataupun lebih yang memiliki tujuannya masing-masing dalam mengikatkan dirinya kepada perjanjian tersebut atas dasar kesepakatan Bersama. ${ }^{24}$ Dalam penyelenggaraan pinjaman online hal tersebut dilakukan oleh konsumen selaku penerima pinjaman dana melakukan transaksi sesuai dengan kesepakatan Bersama pelaku usaha pinjaman online P2P Lending yang akan menimbulkan kewajiban timbal balik diantara mereka yang akan memunculkan perjanjian dan konsekuensi yang harus sama-sama dipenuhi dari setiap pihak tersebut. ${ }^{25}$

Dalam hukum perdata kegiatan pinjam meminjam merupakan suatu aktivitas yang sudah pasti terjadi setiap harinya sudah tentu menghasilkan perjanjian kepada setiap pihak yang mau mengikatkan dirinya. Sesuai syarat sahnya perjanjian ada 4 yaitu pertama adalah adanya kesepakatan, yang kedua ialah kecakapan umur dari masing-

20 Ahmad Miru, (2011). Prinsip-Prinsip Perlindungan Hukum Bagi Konsumen Di Indonesia: Jakarta. Raja Grafindo. h.21.

21 Siti Yuniarti, (2018), Konsumen dan Fintech, retrieved from: https://businesslaw.binus.ac.id/2018/12/31/konsumen-dan-fintech/.

22 Adi Setiadi Saputra. (2018). Perlindungan Terhadap Pemberi Pinjaman Selaku Konsumen dan Tanggung Jawab Penyelenggara Peer to Peer Lending Dalam Kegiatan Peer to Peer Lending di Indonesia, Jurnal Universital Katolik Parahyangan. DOI: 10.25123/vej.3057.h. 252.

${ }^{23}$ Lihat Republik Indonesia. Undang-Undang Tentang Perlindungan Konsumen . UU No. 8 Tahun 1999. LN Tahun 1999 No.42. TLN No. 3821. Diundangkan Tanggal 20 April 1999. Ketentuan Pasal 1 angka 3.

${ }^{24}$ Lihat Republik Indonesia. Kitab Undang-Undang Hukum Perdata. Staatsblaad No. 23 Tahun 1847. Diundangkan Tanggal 30 April 1847. Ketentuan Pasal 1313.

25 Ibid. h. 247. 
masing pihak, syarat ketiga adalah adanya hal tertentu, serta syarat terakhir atau ke empat adalah sebab yang tidak melanggar hukum. ${ }^{26}$ Dari adanya kesepakatan diatas sudah pasti tentu memiliki dampak berupa hak dan kewajiban bagi setiap pihaknya, namun jika dalam prakteknya pihak yang memiliki kewajiban tidak melaksanakannya maka pihak yang dirugikan dapat melakukan tuntutan hukum sesuai pasal 1365 KUHPer. Perlindungan hukum berhubungan dengan kesepakatan dan perjanjian karena apabila terdapat pelanggaran sepihak dari yang sudah disepakati maka orang yang dirugikan atas perbuatan sepihak oleh kreditur harus dilindungi dan ini merupakan tujuan dari adanya pengaturan pada pasal tersebut, maka dari itu debitur selaku konsumen memiliki hak dalam mendapatkan penyelesaian hukum atas kerugian yang ditimbulkan oleh kreditur. ${ }^{27}$

Dalam perkembangan bisnis Fintech terkait penyimpanan data privasi konsumen teknologi yang digunakan umumnya disebut Blockchain, yang berarti database buku besar yang menyimpan daftar catatan atau transaksi data yang terus bertambah. Singkatnya blockchain adalah alat baru untuk mengirim dan mengenkripsi segala jenis transaksi di website yang memiliki otoritas terpusat untuk memvalidasi tindakan. ${ }^{28}$ Oleh karena itu data tidak hanya memberikan manfaat bagi individu atau entitas bisnis melainkan juga penyebab masalah hukum jika tidak dikelola dengan baik, seperti misalnya kasus dalam bisnis pinjaman online fintech P2P Lending dimana pihak ketiga selaku debt collector dari pihak penyelenggara melakukan penyebarluasan data pribadi konsumen penerima pinjaman dana dan hal tersebut merugikan dirasa merugikan mereka. ${ }^{29}$

Adapun data pribadi konsumen harus dikelola dengan prinsip prinsip informasi yang adil (fair information practices), prinsip ini merupakan prinsip standar yang digunakan dalam praktik oleh sector public atau swasta sehingga privasi konsumen terlindungi. ${ }^{30}$ Fair Information Principles adalah sebagai berikut: ${ }^{11}$

1. Prinsip pembatasan (collection limitation): pengumpulan informasi pribadi masyarakat harus dibatasi dengan tujuan semula

2. Penyebaran informasi (disclosure): individu harus diberi informasi tujuan pengumpulan dan penyebaran informasi

3. Penggunaan kedua (secondary usage): individu dapat menolak atas pihak lain untuk mengoleksi informasi pribadinya tanpa meminta persetujuan terlebih dahulu

4. Mengkoreksi data (record correction): harus ada mekanisme yang memungkinkan seseorang untuk dapat mengkoreksi informasi mereka

5. Keamanan (security): Badan-badan pemerintah yang mengelola, mengumpulkan informasi pribadi seorang wajib menjamin keamanan

${ }^{26}$ Lihat Republik Indonesia. Kitab Undang-Undang Hukum Perdata. Staatsblaad No. 23 Tahun 1847. Diundangkan Tanggal 30 April 1847. Ketentuan Pasal 1320.

27 Kristiyanti, Celina Tri Siwi. (2011). Hukum Perlindungan Konsumen. CetIII.Jakarta. Sinar Grafka. h.38.

28 Dian Purnama Anugerah and MasitohIndriani (2018). Data Protection In Financial Technology Services (A Study In Indonesia Legal Perspective ). Sriwijaya Law Review. ISSN: 2541-6464. v1.i2. h.5

29 Ibid.

30 Shinta Dewi, (2009). Cyberlaw. Bandung. Widya Padjajaran. h. 48.

31 Ibid. h. 49. 
informasi yang dikelolanya untuk menghindari terjadinya penyalahgunaan informasi oleh orang lain.

Fungsi dari Kepastian Hukum adalah perlindungan akibat hak mereka sebagai pihak korban dirasa dirugikan oleh pihak lain, ${ }^{32}$ sebagai konsumen yang menerima pinjaman juga tak luput dari perlindungan hukum terutama dalam hal ini kerahasiaan data diri dari konsumen oleh penyelenggara P2P Lending. Adapun prinsip fundamental untuk perlindungan data pribadi konsumen di Indonesia diatur dalam Pasal 28 huruf (G) Undang-Undang Dasar Negara Republik Indonesia Tahun 1945, yang menyatakan bahwa setiap orang berhak atas perlindungan diri pribadi, keluarga harkat martabat dan harta benda yang berada dibawah kekuasaannya dan serta berhak atas rasa aman dari ancaman ketakutan yang mengancam.

Perlindungan data pada umumnya didefinisikan sebagai undang-undang yang dirancang untuk melindungi informasi pribadi apakah dikumpulkan, diproses, dan disimpan yang dimaksudkan sebagai bagian dari sistem pengarsipan. ${ }^{33}$ Perlindungan data pribadi adalah upaya dan sarana dalam memberikan jaminan kepastian hukum kepada individu yang terkait dengan pemanfaatannya. Segala informasi yang berkaitan dengan identifikasi subjek data seseorang baik secara langsung ataupun tidak langsung merupakan data pribadi konsumen, ${ }^{34}$ makanya Perlindungan data pribadi konsumen dalam layanan Fintech berbasis P2P Lending adalah hal yang sangat penting untuk membangun kepercayaan konsumen. Prinsip-prinsip perlindungan data dan kaitannya dengan privasi konsumen harus dipenuhi oleh penyedia layanan untuk melindungi konsumen, prinsip-prinsip tersebut diantaranya prinsip pengumpulan, prinsip pembatasan, prinsip kualitas data, prinsip tindakan keamanan, prinsip keterbukaan, partisipasi individu dan prinsip akuntabillitas. ${ }^{35}$

Indonesia tidak memiliki peraturan hukum spesifik yang mengatur masalah perlindungan pribadi dan kehidupan keluarga, hanya peraturan data pribadi yang saat ini relevan. ${ }^{36}$ Adapun perlindungan data pribadi dapat ditemukan dalam UndangUndang No. 11/2008 mengenai Informasi Transaksi Elektronik (UU ITE), yang sudah dirubah dengan Undang-Undang No.19/2016 mengenai Perubahan Atas UndangUndang Nomor 11 Tahun 2008 Tentang Informasi dan Transaksi Elektronik dan serta Peraturan Pemerintah No. 82/2012 mengenai Penyelenggaraan Sistem dan Transaksi Elektronik. Dari tiga peraturan tadi tidak ditemukan regulasi yang menjelaskan seperangkat ketentuan detail komprehensif untuk perlindungan data pribadi, melainkan hanya sebuah gagasan secara umum tentang perlindungan data pribadi tanpa adanya pedoman khusus. ${ }^{37}$ Untuk mengatasi penyebaran data pribadi konsumen secara ilegal, maka secara tehknis dikeluarkan Peraturan tentang Perlindungan Data Pribadi melalui pengaturan secara teknis lewat peraturan Menteri Komunikasi dan Informatika Nomor 20 tahun 2016 (Permen PDP) , Peraturan ini adalah sebuah mandat

32 Aminanto, (2017), Human Right Civil and Political Right in Law Country. Jember: Jember Katamedia: h. 51

${ }^{33}$ Shinta Dewi. Op.Cit. h. 7

${ }^{34}$ Ibid.

35 Ibid. h. 8

36 SSEK Legal Consultant. (2019). Data Protection \& Cybersecurity. Available From https://www.ssek.com/images/publication_file/1694/chambers-data-protection-cybersecurity-2019-guide.pdf.

37 Ibid. 
dari Pasal 13 Ayat (3) dari PP No.82/2012 sebagai implementasi dari sistem elektronik dan transaksi.

Dalam yurisdiksi di negara-negara lain pada umumnya mereka membentuk peraturan perlindungan data pribadi mengacu pada instrumen internasional seperti misalnya the General Data Protection Regulation atau disebut (GDPR), GDPR adalah regulasi hukum untuk perlindungan data pribadi dan privasi untuk semua penduduk di European Union (EU) dan European Economic Area (EEA). ${ }^{38}$ GDPR bertujuan terutama untuk memberikan kontrol kepada individu atas data pribadi mereka dan untuk menyederhanakan lingkungan regulasi untuk bisnis internasional dengan menyatukan regulasi di dalam UE. ${ }^{39}$ Perlindungan data pribadi konsumen saat ini di Indonesia kurang berkembang karena Peraturan Menteri Komunikasi dan Informatika Nomor 20 Tahun 2016 tentang Perlindungan Data Pribadi Pada Sistem Elektronik (Permen PDP) tidak mengakui konsep seperti pengontrol data, pengolah data, sensitif data pribadi, petugas perlindungan data konsumen secara khusus, ${ }^{40}$ namun prinsip-prinsip umum tertentu dalam GDPR terkait untuk pemrosesan informasi pribadi telah diadopsi dalam Permen PDP antara lain keabsahan, kerahasiaan, tujuan, Batasan, ketepatan, dan batasan penyimpanan. ${ }^{41}$ Adapun ruang lingkup Permen PDP mencangkup berbagai hal yang berhubungan dengan data pribadi konsumen seperti perlindungan terhadap bagaimana perolehan data pribadi, cara mengumpulkan data, mengolah data pribadi, menganalisis keaslian dari data pribadi konsumen, menyimpan data pribadi dengan benar oleh pihak penyelenggara, pengumuman, serta penyebarluasan data pribadi, serta dilakukan pemusnahan. ${ }^{42}$

Setiap pengaturan hukum menyatakan bahwa data pribadi setiap konsumen atau individu harus dilindungi karena harus di simpan, dipelihara, dan dijaga kebenaran dan kerahasiaannya agar tidak tersebar luas. ${ }^{43}$ Di samping Permen PDP tersebut, keberadaan OJK sebagai lembaga pengawas diharapkan bisa memberikan perlindungan maksimal terhadap konsumen fintech atas perbuatan yang merugikan dari pihak penyelenggara pinjaman online berbasis teknologi informasi. ${ }^{4}$

Terkait dengan layanan keuangan berbasis teknologi informasi yang bersinggungan secara langsung dengan data pribadi, OJK mengeluarkan peraturan khusus yaitu POJK Layanan P2P Lending dan untuk melanjutkan implementasi serta pengaturan POJK tadi, tahun 2017 Otoritas Jasa Keuangan mengeluarkan ketentuan pelaksana tentang Tata Kelola serta Manajemen Risiko dalam Kegiatan Layanan Pinjam Meminjam Online melalui Surat Edaran No.18/SEOJK.02/2017 yang ditetapkan tanggal 18 April

38 Wikipedia. General Data Protection Regulation. Available From https://en.wikipedia.org/wiki/General_Data_Protection_Regulation (diakses 12 Oktober 2019).

39 Ibid.

40 Abadi Abi Tisnadisastra, et.all, (2019). Data Protection \& Privacy 2020. Law Bussiness Research. ISBN 978-1-83862-146-9. Page 5.

41 Ibid.

42 Lihat Republik Indonesia. Peraturan Menteri Komunikasi dan Informatika Tentang Perlindungan Data Pribadi. Permenkominfo No. 20 Tahun 2016. BN Tahun 2016 No.1829. Diundangkan Tanggal 1 Desember 2016. Ketentuan Pasal 2 ayat (1).

43 One Trust Data Guidance, Personal Data Protection Regulations. Available From https://free.dataguidance.com/laws/indonesia-personal-data-protection-regulations/

44 Lihat Republik Indonesia. Undang-Undang Tentang Otoritas Jasa Keuangan . UU No.21 Tahun 2011. LN Tahun 2011 No. 111. TLN No. 5253. Ketentuan Pasal 4 Huruf c. 
2017 (SEOJK P2P Lending) adapun data pribadi yang harus dilindungi dalam Bab VI terkait Pengelolaan Data dan Informasi adalah:

a. Untuk data pribadi perseorangan, adapun yang menjadi perhatian seperti: nama seseorang, alamat domisili pihak yang bersangkutan, Kartu Identitas Penduduk (KTP), Nomor Pokok Wajib Pajak dari konsumen serta informasi riskan terkait lainnya wajib untuk disimpan dan dilindungi kerahasiaannya serta tidak disebarluaskan .

b. Untuk data Korporasi adapun yang harus di jaga kerahasiannya seperti datadata penting dari korporasi tersebut, mulai dari nama dan lain sebagainya .

c. Data dan informasi yang bersifat privasi yang bersifat material termasuk data transaksi keuangan dan juga kontrak

Terhadap data diatas penyelenggara dilarang untuk melakukan penyebarluasan kepada pihak lainnya, peraturan tersebut menjadi sumbu utama dalam perlindungan konsumen yang berkecimpung dalam sektor jasa keuangan berbasis teknologi informasi dan satu kesatuan yang menjadi prinsip yang harus dipatuhi oleh setiap pelaku usaha penyelenggaraan Fintech $P 2 P$ Lending. .5

\subsection{Akibat Hukum Terhadap Tindakan Menekan Pembayaran Kepada Konsumen Gagal Bayar Dengan Cara Melawan Hukum.}

Perbuatan yang dilakukan oleh seseorang dan berkaitan dengan kesalahan perdata karena hal tersebut berdampak kerugian pada orang lain merupakan perbuatan melawan hukum. ${ }^{46}$ Atas perbuatannya tersebut maka harus ada tanggung jawab atas kerugian yang ditimbulkan pada orang lain. Perbuatan melawan hukum salah satunya dilakukan oleh pihak ketiga sebagai debt collector, dimana salah satu contoh kasus P2P Lending yang menjadi sorotan di Indonesia mengenai pemberitaan penagihan kredit hutang atas pinjaman gagal bayar oleh debt collector perusahaan pinjaman online $(P 2 P$ Lending) terhadap konsumen selaku nasabah peminjam dana, ini menimbulkan beberapa permasalahan terutama dalam melakukan penagihan hutangnya kepada konsumen sebagai nasabah. Salah satu kasus ini terjadi pada tahun 2018 kemarin dimana Rupiah Plus selaku platform yang terdaftar dalam OJK adalah platform kredit pinjaman online tanpa agunan yang dimiliki PT Digital Synergy Technology . Dalam kasus ini Rupiah Plus yang diwakili oleh pihak ketiga melakukan penagihan pinjaman gagal bayar kepada konsumen selaku debitur yang telat membayar atau memenuhi prestasinya dalam waktu yang sudah ditentukan untuk membayar hutang dari uang yang dipinjam, adapun nasabah yang menjadi korban bernama Febriyan yang berasal dari Depok Jawa Barat. Hal yang menjadi masalah di sini bukanlah pinjaman gagal bayarnya namun cara penagihan yang dilakukan dengan cara menghubungi orang lain yang tidak ada hubungannya dengan peminjam dana, nomor telepon tersebut didapatkan dari akses kontak peminjam yang gagal bayar dan tentu saja ini dilakukan tanpa ijin dari konsumen. ${ }^{47}$

45 Siti Yuniarti. OpCit.

46 Lihat Republik Indonesia. Kitab Undang-Undang Hukum Perdata. Staatsblaad No. 23 Tahun 1847. Diundangkan Tanggal 30 April 1847. Ketentuan Pasal 1365.

47 Dea Chadiza Syafina (2018). Kasus Rupiah Plus, Saat Urusan Utang Meneror Data Pribadi. Available from https://tirto.id/kasus-rupiahplus-saat-urusan-utang-meneror-data-pribadicNVl, 
Dalam kasus ini debt collector pihak penyelenggara sebagai pemberi pinjaman online dianggap lalai dan melanggar hukum karena menyebarkan data pribadi atau kontak nasabah penerima pinjaman tanpa persetujuan dari konsumen penerima pinjaman yang bersangkutan, debt collector melakukan penagihan yang bukan sewajarnya dengan cara mengancam korban, kemudian penagihan hutang juga dilakukan dengan menghubungi kontak darurat yang diisi apabila terjadi hal-hal darurat, fungsi dari kontak darurat tersebut sudah pasti akan dihubungi apabila terjadi wanprestasi dari pihak konsumen yang meminjam. Dalam kasus ini pihak ketiga selaku debt collector juga mengakses tanpa ijin kontak yang ada dalam daftar telepon konsumen peminjam dana dan menghubungi serta menyebarluaskan informasi pribadi pada pihak yang tidak ada sangkut pautnya mengenai hutang peminjam, hal itu sudah tentu merugikan nama baik konsumen dan melanggar privasi pihak lain akibat tersebarnya kontak telepon tanpa persetujuan yang jelas, adapun konsekuensi dari kejadian tersebut sekitar 21,48\% laporan yang diterima dipecat karena tindakan yang dilakukan debt collector, cara penagihan hutang oleh Rupiah Plus sudah melewati ranah pribadi karena menerapkan pola persekusi digital, team Investigasi Komunitas Monitor Fintech mendapatkan data bahwa 89\% (delapan puluh sembilah persen) dari penerima dana pinjaman online adalah korban penyebaran data oleh oknum debt collector.

Adapun contoh kegiatan yang menyangkut data pribadi konsumen dalam Lembaga keuangan yang dilakukan dengan tanpa itikad baik yaitu: 48

1. Pihak penyelenggara meminta data pribadi pengguna selaku konsumen padahal belum bisa memberikan layanan terbaik yang dapat diberikan untuk pengguna;

2. Pihak penyelenggara sengaja mengumpulkan data pribadi konsumen yang tidak ada kaitannya sama sekali dengan penawaran layanan serta menggunakan data pribadi konsumen tersebut dengan tujuan tidak jelas bahkan cenderung berujung merugikan konsumen

3. Pihak penyelenggara mengumpulkan serta menyimpan data pribadi konsumen meskipun mereka tidak mempunyai sistem yang memadai untuk menyimpan data pribadi

Sebagai pihak penerima pinjaman yang diancam dan dirugikan atas tindakan penyebarluasan data privasi dan pribadi, nasabah pinjaman online tetap memiliki hak dan kewajiban yang harus dilindungi dari kegiatan yang tidak terpuji tersebut. Konsumen perlu untuk mengetahui hak-haknya agar mereka bisa bertindak dan mengambil langkah yang tepat sesuai prosedur hukum. Adapun hak konsumen itu sendiri seperti hak untuk berpendapat terutama terkait barang/jasa pelayanan yang dipergunakan saat kejadian, konsumen yang dirugikan patut untuk dilindungi saat menyelesaikan sengketa perlindungan konsumen karena mereka mempunyai kedudukan yang sama didepan hukum maka sudah tentu memiliki hak untuk mendapatkan advokasi termasuk perlindungan hukum. ${ }^{49}$ Sebagai pihak penerima pinjaman dana dari pinjaman online P2P Lending yang menjadi korban pencemaran nama baik oleh penyelenggara $P 2 P$ Lending maka berhak untuk mendapatkan perlindungan hukum yang adil, atas ancaman dan intimidasi serta penyebaran data pribadi karena tindakan yang sudah dilakukan merugikan pihak penerima pinjaman.

48 Siti Yuniarti, Loc.Cit.

${ }^{49}$ Happy Susanto, (2008). Hak-Hak Konsumen Jika Dirugikan . Jakarta.Ciganjur. h.23. 
Dalam Hukum Perdata, hutang merupakan suatu kewajiban yang harus dibayar oleh peminjam online, apabila terjadi wanprestasi karena ketidaksanggupan dalam membayar maka akan menimbulkan resiko denda yang semakin bertambah. Prinsip Itikad Baik dalam penyelesaian klausula perdata sangat dianjurkan, dimana para pihak melakukan musyawarah melalui mediasi pengadilan dengan gugatan perdata yang diajukan sebelumnya. Nasabah selaku konsumen diwajibkan untuk beritikad baik dengan pihak penyelenggara fintech P2P Lending dalam hal terjadi gagal bayar, mengenai pelunasan hutang dengan tambahan jangka waktu pembayaran.

Sebagai amanah dari POJK Perlindungan Konsumen, ${ }^{50}$ tujuan dari adanya OJK selain untuk mengawasi juga harus mampu melindungi masyarakat sebagai konsumen atau nasabah terutama dalam sektor jasa keuangan. ${ }^{51}$ Dalam bisnis penyelenggaraan Fintech $P 2 P$ Lending di Indonesia, apabila terdapat sengketa baik antara pihak penyelenggara dan konsumen $P 2 P$ Lending, pihak OJK hanya dapat menerima pengaduan dan menangani kasus fintech legal yang terdaftar dalam OJK, diluar dari itu OJK menganggap bahwa mereka tidak memiliki kewenangan dalam menangani kasus OJK Ilegal, dan OJK menganggap transaksi diatara fintech illegal dan konsumen sudah pasti batal demi hukum.

Mengenai kasus penyebaran data pribadi konsumen gagal bayar tersebut, Rupiah Plus selaku penyelenggara fintech P2P Lending telah melanggar kewajiban Pelaku Jasa Keuangan untuk melakukan pengawasan dan pencegahan dari tindakan penyalahgunaan kewenangan terhadap setiap pegawainya. ${ }^{52}$ Termasuk kewajiban pelaku usaha untuk melindungi data pribadi konsumen penerima dana dengan tidak memberikan data pribadi konsumen kepada siapapun karena hal tersebut dilarang. ${ }^{53}$ Namun larangan ini tidak berlaku apabila konsumen mengijinkan dengan adanya pernyataan tertulis, dan/atau karena ada kewajiban dari peraturan perundangundangan. Sudah jelas bahwa pihak penyelenggara harus menyimpan kerahasiaan data konsumen penerima pinjaman uang dari siapapun dan wajib untuk mencegah setiap pegawainya menggunakan kewenangannya untuk merugikan konsumen dan dalam kasus Rupiah Plus di atas, pihak Rupiah Plus melakukan pembiaran terhadap pihak ketiga selaku debt collector dalam melakukan kegiatan yang sudah melanggar hukum dan merugikan konsumen, dan hal tersebut berarti pelaku usaha wajib

50 Republik Indonesia.Peraturan Otoritas Jasa Keuangan Tentang Layanan Pinjam Meminjam Uang Berbasis Teknologi Informasi. POJK No.77/POJK.01/2016. LN Tahun 2016 No 324. Diundangkan Tanggal 26 Desember 2016.

51 Basrowi. (2019). Analisis Aspek dan Upaya Perlindungan Konsumen Fintech Syariah. Lex Librum: Jurnal Ilmu Hukum. Vol 5 Nomor 2 Page : 959-980. doi : http://doi.org/10.5281/zenodo.3187539. p 969.

52 Lihat Republik Indonesia.Peraturan Otoritas Jasa Keuangan Tentang Layanan Pinjam Meminjam Uang Berbasis Teknologi Informasi. POJK No.77/POJK.01/ Tahun 2016. LN Tahun 2016 No 324. Diundangkan Tanggal 26 Desember 2016. Ketentuan Pasal 30 Ayat 1 huruf $b$

${ }^{53}$ Lihat Republik Indonesia.Peraturan Otoritas Jasa Keuangan Tentang Layanan Pinjam Meminjam Uang Berbasis Teknologi Informasi. POJK No.77/POJK.01/ Tahun 2016. LN Tahun 2016 No 324. Diundangkan Tanggal 26 Desember 2016. Ketentuan Pasal 31. 
bertanggung jawab apabila terjadi kesalahan dan kelalaian atas penggunaan data pribadi. ${ }^{54}$

Adapun unsur kesalahan yang dimaksud adalah lalai pada saat bertugas dan mejalankan kewajibannya dalam kegiatan penyelenggaraan pinjaman online termasuk juga pihak ketiga yang diberikan tugas untuk melaksanakan kewajibannya dalam penagihan hutang guna kepentingan dari pelaku usaha sebagai penyelenggara layanan. Prinsip tanggung jawab dalam Pasal 37 POJK Layanan P2P Lending sangat penting karena hal tersebut berkaitan erat dengan perlindungan, karena tanggung jawab muncul atas adanya kerugian ataupun pelanggaran terhadap hak-hak konsumen selaku penerima pinjaman yang memunculkan konsekuensi pertanggunjawaban.

Ditinjau dari UU ITE itu sendiri, kasus penagihan uang dengan mengakses data pribadi konsumen dan menyebarkannya data tersebut ke orang lain serta mencemarkan nama konsumen ke orang lain merupakan suatu perbuatan melawan hukum, adapun salah satu unsur melawan hukum ialah kesengajaan dari debt collector dan kerugian bagi konsumen selaku penerima pinjaman online dan pemilik hutang. ${ }^{55}$ Oleh karena itu berdasarkan kasus yang telah dijelaskan tadi maka pihak Rupiah Plus dikenakan sanksi sesuai dengan UU ITE dan POJK Layanan P2P Lending. Adapun tindakan dari pihak ketiga dari Rupiah Plus selaku penyelenggara pinjaman online terkait penyebaran data pribadi kepada pihak lain yang tidak ada kaitannya dengan hutang sudah dapat dikatagorikan sebagai tindakan pencemaran nama baik konsumen dan akibat sanksinya bisa dikenakan pidana atau penjara serta denda, adapun sanksi yang akan diterima adalah denda paling banyak satu miliar rupiah dan hukuman enam tahun penjara. 56

Selain sanksi pidana, tindakannya melakukan penyebarluasan data pribadi konsumen juga dikenakan sanksi administrasi dari OJK dalam hal apabila terjadi pelanggaran kewajiban dan tidak mengindahkan larangan-larangan yang diatur dalam peraturan OJK ini berupa peringatan dalam bentuk surat tertulis, atau kewajiban agar pelaku usaha membayar uang dengan jumlah tertentu, kegiatan usaha yang dibatasi bahkan ijin kegiatan usaha yang dicabut. ${ }^{57}$

Pengenaan sanksi administratif oleh OJK adalah salah satu bentuk dalam menjalankan tugas pengawasan yang dimaksud pada Pasal 6 UU OJK, dalam pasal 9 UU OJK, disebutkan bahwa OJK memiliki wewenang dalam menetapkan sanksi administrative terhadap pihak yang melakukan pelanggaran terhadap peraturan perundangundangan di sector jasa keuangan, sanksi administrasi dalam hal penyelenggaraan P2P Lending ini diatur lebih lanjut dalam Pasal 47 POJK P2P Lending yang menyebutkan

${ }^{54}$ Lihat Republik Indonesia.Peraturan Otoritas Jasa Keuangan Tentang Layanan Pinjam Meminjam Uang Berbasis Teknologi Informasi. POJK No.77/POJK.01/Tahun 2016. LN Tahun 2016 No 324. Diundangkan Tanggal 26 Desember 2016. Ketentuan Pasal 37.

55 Lihat Republik Indonesia. Kitab Undang-Undang Hukum Perdata. Staatsblaad No. 23 Tahun 1847. Diundangkan Tanggal 30 April 1847. Ketentuan Pasal 1365.

56 Lihat Republik Indonesia. Undang-Undang Tentang Informasi dan Transaksi Elektronik. UU No. 11 Tahun 2008. LN Tahun 2008 No. 58. TLN No. 4843. Diundangkan Tanggal 21 April 2008. Ketentuan Pasal 27 ayat (3) dan Pasal 45.

57 Lihat Republik Indonesia. Peraturan Otoritas Jasa Keuangan Tentang Layanan Pinjam Meminjam Uang Berbasis Teknologi Informasi. POJK No.77/POJK.01/2016. LN Tahun 2016 No 324. Diundangkan Tanggal 26 Desember 2016. Ketentuan Pasal 47. 
bahwa atas pelanggaran kewajiban dan larangan dalam peraturan OJK, OJK berwenang mengeluarkan sanksi tertulis berupa:
a. Peringatan tertulis
b. Denda
c. Pembatasan kegiatan usaha
d. Pencabutan izin.

Sanksi administratif baru dapat diberikan oleh OJK setelah OJK menerima laporan dari pihak-pihak yang merasa dirugikan, selanjutnya dilakukan pemeriksaan dan apabila Pelaku usaha pinjaman online yang sudah terdaftar terbukti bersalah melakukan pelanggaran terhadap peraturan perundang-undangan maka akan dijatuhkan sanksi administratif. Peringatan tertulis akan diberikan oleh OJK agar untuk selanjutnya yang bersangkutan tidak mengulangi perbuatannya dan tidak merugikan pihak lain. Kemudian sanksi denda adalah kewajiban yang diberikan oleh OJK kepada yang bersangkutan untuk membayar sejumlah uang akibat hukum yang ditimbulkan dan sudah merugikan beberapa pihak. Pembatasan kegiatan usaha merupakan pembatasan terhadap pelaku usaha pinjaman online dalam menerima nasabah untuk kurun waktu tertentu, hal tersebut dilakukan mengingat tindakan penyebarluasan data konsumen dikhawatirkan akan tetap terjadi apabila itu terus dibiarkan, maka pembatasan tersebut dilakukan agar tidak merugikan pihak konsumen selaku nasabah pinjaman online. Untuk sanksi terakhir ialah pencabutan izin yang dijatuhkan kepada pelaku usaha pinjaman online, penjatuhan sanksi ini menyebabkan penyelenggara pinjaman online tidak mungkin menjalankan usahanya kembali karena izin sudah dicabut oleh OJK.

\section{Kesimpulan}

Kedudukan hukum selaku debt collector dengan pihak penyelenggara pinjaman online P2P Lending adalah sebagai pihak ketiga dalam hubungan kerja sama yang dimana tiap pihak memiliki kewajiban masing-masing. Selaku Debt collector bertanggung jawab untuk melakukan penagihan pinjaman terhadap konsumen yang gagal bayar, hal tersebut dijelaskan dalam kode etik yang dikeluarkan oleh AFPI terkait izin penggunaan pihak ketiga dalam penyelenggaraan fintech P2P Lending, penagihan.

Walaupun telah ada regulasi mengenai larangan penyebarluasan data konsumen secara illegal, namun pada prakteknya tetap saja pihak penyelenggara Fintech P2P Lending melakukan kelalaian dalam pengawasan terhadap Debt collector selaku pihak ketiga yang melakukan penagihan dengan cara melawan hukum terhadap konsumen selaku nasabah penerima pinjaman yang gagal bayar (wanprestasi) dan tentu hal tersebut pelaku usaha telah lalai melakukan tugasnya terkait kewajibannya untuk melakukan pengawasan dan pencegahan atas tindakan penyalahgunaan kewenangan yang dilakukan oleh. Penyelenggara dalam hal ini tidak melakukan kontrol terhadap kinerja dari debt collector mereka dan melakukan pembiaran maka dari itu melanggar Pasal 30 Ayat (1) huruf b POJK Layanan P2P Lending, selain itu Rupiah Plus selaku penyelenggara pinjaman online seharusnya tidak memberikan data konsumen pada pihak ketiga karena hal tersebut melanggar hukum. Penyebaran data pribadi konsumen nasabah dengan tanpa izin yang dilakukan oleh debt collector dari Rupiah Plus sudah melanggar privasi konsumen dan mengganggu kenyamanan orang lain, 
karena tindakan tersebut dirasa kurang wajar dan menimbulkan akibat hukum berupa pencemaran nama baik dari konsumen selaku peminjam, maka dari itu konsumen dapat membuat tuntunan atas kerugian yang timbul dan atas perbuatan yang dilakukan Rupiah Plus maka dapat dikenakan sanksi pidana berupa pidana enam tahun juga termasuk denda satu miliar serta dapat dikenakan sanksi administratif berdasarkan POJK Layanan P2P Lending yang dikeluarkan oleh OJK.

\section{Daftar Pustaka}

\section{Buku}

Aminanto, (2017). Human Right Civil and Political Right in Law Country, Jember Katamedia.

Hajati, S., Winarsi, S., Sekarmadji, A., \& Moechtar, O. (2020). Buku Ajar Politik Hukum Pertanahan. Airlangga University Press.

Handri Raharjo. (2018). Sistem Hukum Indonesia: Ketentuan-ketentuan Hukum Indonesia dan Hubungannya dengan Hukum Internasional. Media Pressindo.

Kristiyanti, Celina Tri Siwi. (2011). Hukum Perlindungan Konsumen. Cet III. Jakarta: Sinar Grafika.

Muhammad, A. (2004). Hukum dan Penelitian Hukum, Bandung: PT. Citra Aditya Bakti.

Miru, A. (2011). Prinsip-prinsip perlindungan hukum bagi konsumen di Indonesia. Jakarta: Raja Grafindo.

Soekanto, Soerjono. (2007). Pengantar Penelitian Hukum. Cet.III. Jakarta: Universitas Indonesia

Soekanto, Soerjono, Sri Mamuji (2010). Penelitian Hukum Normatif suatu Tinjauan Singkat. jakarta: Raja Grafindo Persada.

\section{Jurnal/Proseding:}

Basrowi, B. (2019). Analisis Aspek Dan Upaya Perlindungan Konsumen Fintech Syariah. Lex Librum: Jurnal Ilmu Hukum, 5(2), 959-980.

Jørgensen, T. (2018). Peer-to-Peer Lending-A New Digital Intermediary, New Legal Challenges. Nordic Journal of Commercial Law, (1), 30-30. https://doi.org/10.5278/ojs.njcl.v0i1.2491

Lin, T. C. (2015). Infinite financial intermediation. Wake Forest L. Rev., 50, 643.

Muchlis, R. (2018). Analisis SWOT Financial Technology (Fintech) Pembiayaan Perbankan Syariah Di Indonesia (Studi Kasus 4 Bank Syariah Di Kota Medan). AT-TAWASSUTH: Jurnal Ekonomi Islam, 1(1), 335-357. http://dx.doi.org/10.30821/ajei.v1i1.2735

Saputra, R. Analisis Hukum Penggunaan Jasa Pihak Ketiga (Debt Collector) Dalam Upaya Penyelesaian Kartu Kredit Macet Pada Bank Danamon Indonesia Tbk (Studi Putusan No. 751/PDT. G/2014/PN. JAK. SEL). JURNAL CIVIL LAW USU, 1(6).

Saputra, A. S. (2019). Peer To Peer Lending Di Indonesia dan Beberapa Permasalahannya. Veritas et Justitia, 5(1), 238-261. https://doi.org/10.25123/vej.3057

Yunus, U. (2019, June). A Comparison Peer to Peer Lending Platforms in Singapore and Indonesia. In Journal of Physics: Conference Series (Vol. 1235, No. 1, p. 012008). IOP Publishing. 
Zulaikha, S., Rofiah, K., \& Pertiwi, R. S. (2019). Legal Protection of Lenders in the Implementation of Financial Technology Based on Peer to Peer Lending. KnE Social Sciences, 1305-1316.

\section{$\underline{\text { Skripsi }}$}

Sari, A. R. (2018). Perlindungan Hukum Bagi Pemberi Pinjaman Dalam Penyelenggaraan Financial Technology Berbasis Peer to Peer Lending di Indonesia. Skripsi, Universitas Islam Indonesia. Available from: https://dspace.uii.ac.id/handle/123456789/8313

\section{Internet}

Desai, Fagulni. 2015. The Evolution of Fintech. Forbes. Diakses pada https://www.forbes.com/sites/falgunidesai/2015/12/13/the-evolution-offintech/\#3032d04d7175

Yuniarti, Siti, 2018, Konsumen dan Fintech, Binus University, Faculty of Humanities. Diakses pada https://business-law.binus.ac.id/2018/12/31/konsumen-danfintech/

SSEK Legal Consultant. (2019). Data Protection \& Cybersecurity. Diakses pada https://www.ssek.com/images/publication_file/1694/chambers-dataprotection--cybersecurity-2019-guide.pdf

Wikipedia. General Data Protection Regulation. Wikipedia Diakses pada https://en.wikipedia.org/wiki/General_Data_Protection_Regulation

One Trust Data Guidance, Personal Data Protection Regulations. Diakses pada https://free.dataguidance.com/laws/indonesia-personal-data-protection regulations/

Dea Chadiza Syafina (2018). Kasus Rupiah Plus, Saat Urusan Utang Meneror Data Pribadi. Tirto.id. Diakses pada https://tirto.id/kasus-rupiahplus-saat-urusan-utangmeneror-data-pribadi-cNVl

Asosiasi Fintech Pendanaan Indonesia. Pedoman Perilaku. Diakses pada https://www.afpi.or.id/detailsnews/pedoman-perilaku

\section{Ketentuan Hukum Internasional}

The General Data Protection Regulation

\section{Peraturan Perundang-Undangan}

Undang-Undang Dasar Negara Republik Indonesia Tahun 1945

Staatsblad 1847 Nomor 23 tentang Burgerlijk Wetboek Voor Indonesie (BW) atau Kitab Undang-Undang Hukum Perdata

Undang-Undang Nomor 11 Tahun 2008 tentang Informasi dan Transasksi Elektronik Lembaran Negara Republik Indonesia Nomor 58 Tahun 2008

Undang-Undang Nomor 19 Tahun 2016 tentang Perubahan Undang-Undang Nomor 11 Tahun 2008 tentang Informasi dan Transasksi Elektronik Lembaran Negara Republik Indonesia Tahun 2016 Nomor 251

Undang-Undang Nomor 8 Tahun 1999 Tentang Perlindungan Konsumen, Lembaran Negara Republik Indonesia Nomor 42 Tahun 1999

Peraturan Otoritas Jasa Keuangan Nomor 77/POJK.01/2016 tentang Layanan Pinjam Meminjam Uang Berbasis Teknologi Informasi, Lembaran Negara Republik Indonesia Tahun 2016 Nomor 324

Peraturan Menteri Menteri Komunikasi dan Informasi nomor 20 Tahun 2016 tentang 
Perlindungan Data Pribadi dalam Sistem Elektronik, Berita Negara Republik Indonesia Tahun 2016 Nomor 1829

Peraturan Bank Indonesia Nomor 11/11/PBI/ 2009 Tentang Penyelenggaraan

Kegiatan Alat Pembayaran Dengan Menggunakan Kartu, Lembaran Negara Republik Indonesia Tahun 2009 Nomor 64 Dasplem 